\title{
Controlling cell morphology on ion beam textured polymeric surfaces
}

\author{
Emel Sokullu ${ }^{1}$, Fulya Ersoy ${ }^{2}$, Ahmet Öztarhan ${ }^{3}$, Ian G. Brown ${ }^{4}$ \\ ${ }^{1}$ Department of Bioengineering, Faculty of Engineering and Architecture, Izmir Katip Çelebi University, Izmir, Turkey \\ ${ }^{2}$ Department of Biomedical Technologies, Institute of Science, Izmir Katip Çelebi University, Izmir, Turkey \\ ${ }^{3}$ Department of Electrical and Electronics Engineering, Faculty of Engineering, Izmir University, Izmir, Turkey \\ ${ }^{4}$ Lawrence Berkeley National Laboratory, Berkeley, CA, USA
}

\begin{abstract}
Objectives: Nano and micro sized textures on surfaces are generally useful biomaterials. Although the importance of roughness degree has been reported for cell morphology, texture morphology can be more determining for cell adhesion and proliferation. Biodegradable polymers are extensively used as scaffolds as well as implant materials in the human body. The aim of this study was to investigate the effect of ion beam bombardment on cell morphology.

Methods: Gold and carbon ion implantation was made on biodegradable polymers polyglycolic acid, polycaprolactone and polylactic-co-glycolic-acid. Roughness data were obtained from atomic force microscopy. After surface modification with ion beam, B35 neural cells were evaluated on surfaces for cell compatibility. Morphology and cell surface interaction were analyzed with scanning electron microscopy.

Results: We observed improved cell adhesion after ion beam surface modification. Cell adhesion was greater on gold implanted surfaces compared to the carbon implanted. Neural cells attached to lamellar wrinkles, spread by taking the shape of the pattern and exhibited high aspect ratios and axon extension. In contrast, cells that attached on the untreated surfaces remained rounded with low spreading.
\end{abstract}

Conclusion: The findings of this study are important for development of ion beam modified cell cultures and scaffold systems to understand texture-based cell adhesion mechanisms.

Keywords: cell culture; ion implantation; polylactic-co-glycolic acid; surface treatment; topography; wettability

Anatomy 2015;9(3):135-141 @2015 Turkish Society of Anatomy and Clinical Anatomy (TSACA)

\section{Introduction}

Biomaterials have a broad application in biomedical researches due to their biocompatibility, biodegradability characteristics and ease of processing. Specifically, biopolymers have a great potential on cell related applications. A number of different synthetic polymers such as polylactic acid (PLA), polyglycolic acid (PGA), polycaprolactone (PCL) and polylactic-co-glycolic-acid (PLGA) have been used for biomedical applications. The availability of these polymers and the approval of FDA make these materials even desired for the biomedical research. ${ }^{[1]}$
Biomedical researches are strongly dependent on the success of cell attachment on material surfaces. Due to this dependence, most material research focus on improving surface characteristics, thus, increasing cell attachment. There are plenty of techniques to improve surface characteristics of materials including ion implantation and plasma deposition.

Surface modification with ion implantation and plasma deposition has been shown as a viable method to enhance the adhesion properties without affecting the bulk characteristics and modify polymeric surfaces. Despite many complicated effects, the implantation process may generally be envisaged as two major com- 
peting processes: chain scission and crosslinking. In this process, ions are penetrating into a polymer surface by interacting with substrate atoms via electronic (ionization) and nuclear (recoil) interactions. Ionization is the dominant phenomenon and generally leads to crosslinking in adjacent polymer chains, whereas recoils generally lead to chain scission. ${ }^{[1-3]}$ By selecting the appropriate implantation parameters, one can create a three-dimensional cross-linked surface layer with hardness exceeding that of steel in addition to improved wear resistance. ${ }^{[1]}$ Implantation sometimes also results in selective enhancement or reduction of functional chemical groups that can, by modifying the chemical interactions on the polymer surface, change the surface wettability and critical surface tension.

A simple way to evaluate the modified polymeric material surface is by the contact angle with deionized water. The dependence on the circumstance of contact angle is reserved. After implantation, the relaxation or stabilization of the polymer surface gradually occurs as time passes by rearrangement and adsorption of oxygen atoms to induce defects. This results in a gradual change of the contact angle of ion-implanted polymers with time. The contact angle depends on the ion-implanted conditions, the measuring period after implantation, and the reserve circumstance. According to preliminary results and our previous experience, polymers with higher hydrophilicity tend to have good biocompatibility. ${ }^{[2,4-6]}$

In this study, we investigated the effect of ion beam irradiation on B35 cell morphology attached to biodegradable polymers.

\section{Materials and Methods Polymer film preperation}

Samples of poly-L-lactide (PLA; PURASORB PL18 with an inherent viscosity of $1.8 \mathrm{dL} / \mathrm{g}$ ), poly-D, L-lactide-co-glycolide 50/50 (PDLG; PURASORB PDLG 5010 with an inherent viscosity of $1.03 \mathrm{dL} / \mathrm{g})$, and polyL-lactide/caprolactone 70/30 (PLC; PURASORB PLC7015 with an inherent viscosity of $1.63 \mathrm{dL} / \mathrm{g}$ ) were purchased from PURAC (Netherlands) in granule form. As a solvent, chloroform (Merck) was used. PLA, PDLG, and PLC film samples were prepared by a solvent casting method using a $5 \mathrm{wt} \%$ polymer-chloroform solution. Granules were dissolved in chloroform and prepared by casting of the polymer solution on clean glass slides. The solvent was allowed to evaporate slowly at room temperature for $24 \mathrm{~h}$, and the samples were then dried under vacuum at $50{ }^{\circ} \mathrm{C}$.

\section{Surface modification}

The polymer samples were ion implanted using a vacuum arc ion-source-based ion implantation system at the Ege University Surface Modification Laboratory. This facility has been described in detail elsewhere. ${ }^{[5,6]}$ The broad-beam ion source can be repetitively pulsed at rates up to $\sim 50 \mathrm{pulses} / \mathrm{s}$, and the extracted ion beam current can be up to $\sim 1$ A peak or $\sim 10 \mathrm{~mA}$ time averaged. The ion source extraction voltage can be as high as near 100 $\mathrm{kV}$. Mixed metal/gas ion beams can be generated by adding gas to the arc discharge region. In this paper, carbon $(\mathrm{C})$ and (separately) gold $(\mathrm{Au})$ were implanted into polymer-on-glass samples at fluences that varied over the range of $10^{14}-10^{17}$ ions $/ \mathrm{cm}^{2}$ and at ion energies spanning the range of $20-80 \mathrm{keV}$.

\section{Surface characterization}

In order to determine the changes in surface properties, SEM and AFM has been used. Roughness data before and after implantation for each polymer also collected via AFM. Contact angle measurements have been done for the examination of hydrophilicity.

FEI Quanta 200 FEG scanning electron microscopy (SEM) was employed to examine the surfaces of unimplanted, $\mathrm{Au}$ and $\mathrm{C}$ implanted specimens. The results are compared with respect to the reference - untreated PDLG samples.

PSIA XE-100E model atomic force microscopy (AFM) was used to investigate the surface morphology of untreated and $\mathrm{Au}$ and $\mathrm{C}$ implanted PLA, PDLG and PLC. Scan size $5.000 \mu \mathrm{m}$, scan rate $1.001 \mathrm{~Hz}$. and data scale $300.0 \mathrm{~nm}$ were applied through silicon nitride of tip for scanning the sample surfaces. The roughness of untreated and $\mathrm{Au}$ and $\mathrm{C}$ implanted PLA, PDLG and PLC determined with the AFM. XEI software was used for image processing and roughness calculation, in terms of average roughness, $R_{a}$ (the average deviation of the measured z-values from the mean plane), root-meansquare roughness, $R_{\mathrm{q}}$ (standard deviation of an entire distribution of z-values for a large sample size), and maximum roughness, $R_{\max }$ (the difference between the largest positive and negative $\mathrm{z}$-values).

\section{Cell culture}

B35 cells (ATTC, CRL2754) were seeded at a cell density of $4 \times 10^{5}$ cells $/ \mathrm{ml}$ and incubated in a humid, $5 \%$ $\mathrm{CO}_{2}$ cell culture incubator at $37^{\circ} \mathrm{C}$ for $48 \mathrm{~h}$. The cell culture medium was DMEM, Gibco supplemented with $10 \% \mathrm{FBS}, 1 \% \mathrm{~L}$-glutamine, $100 \mathrm{U} / \mathrm{ml}$ penicillin, and 100 
$\mathrm{mg} / \mathrm{ml}$ streptomycin. If otherwise specified, all cell culture reagents were purchased from Biochrom, Germany. After 2-days in culture, the attachment of neural cells on the modified surfaces was observed using SEM (Phillips XL 30S-FEG). The cell viability has been assessed using cell contrast ratio. Morphology and the adhesion points investigated using SEM. Cell contrast ratio was calculated as the ratio of number of cells attached on the implanted sample to that on an untreated sample.

Cell contrast ratio $=\frac{\text { \#of cells attached on ion implanted surface (cell/area) }}{\text { \#of cells attached on pristine surface (cell/area) }}$

\section{Results}

In this study, surface topography of untreated, Au and C implanted biodegradable polymers including PLA, PLC and PDLG were examined with SEM. SEM micrographs were obtained randomly with several measurements (Figure 1). Results represent the surface morphology before and after implantation. We observed the formation of a wide range of surface wrinkling patterns, lamellar and a highly ordered pattern, in swollen poly(Llactide/caprolactone) (PLC) samples.

Wrinkle morphology and size were controlled by the ion beam dose and energy and initial film thickness, respectively. Wrinkle geometry remained stable for gels with equilibrium Young's modulus $>100 \mathrm{kPa}$ (results not shown).

Roughness measurements were performed on PDLG and PLC films for both unimplanted and implanted sam- ples. The treatment of ion bombardment into surface significantly increased the material roughness. The roughness of Au implanted PDLG films increased to 249 $\mathrm{nm}$ and $\mathrm{C}$ implanted ones increased to $213 \mathrm{~nm}$, whereas the roughness of unimplanted films was $79 \mathrm{~nm}$. For PLC films, measurements showed that Au implanted films had the roughness of $254 \mathrm{~nm}$ and $\mathrm{C}$ implanted films had the roughness of $236 \mathrm{~nm}$, whereas the roughness of unimplanted films was $32 \mathrm{~nm}$. Both Au and C ion bombardment increased roughness more than 10 times (Figure 2). Roughness is a desired characteristic for cell attachment and it is known that the rougher surface stimulates the higher cell attachment. Hence, this treatment makes the materials more applicable in the biomedical field due to their improved surface topology.

Different ion doses applied on the material surfaces to examine changes on the surface topography. AFM images in Figure $\mathbf{2}$ show how surface texture changes in nanoscale with respect to ion dosage. When the dose value of ions increased, the cavities on the surface became larger and decreased in number. On the other hand, when we decreased the dose value, the cavities on the surface got smaller but they increased in number. Thus, it is shown that surface texture can easily be controlled by changing the dose value of ions. Ion bombardment significantly changed the surface texture at nanoscale. While there was no surface wrinkles on unimplanted samples, ion bombardment gave surfaces a wrinkled, rough texture which is supposed to stimulate cells to change their morphology (Figure 2).
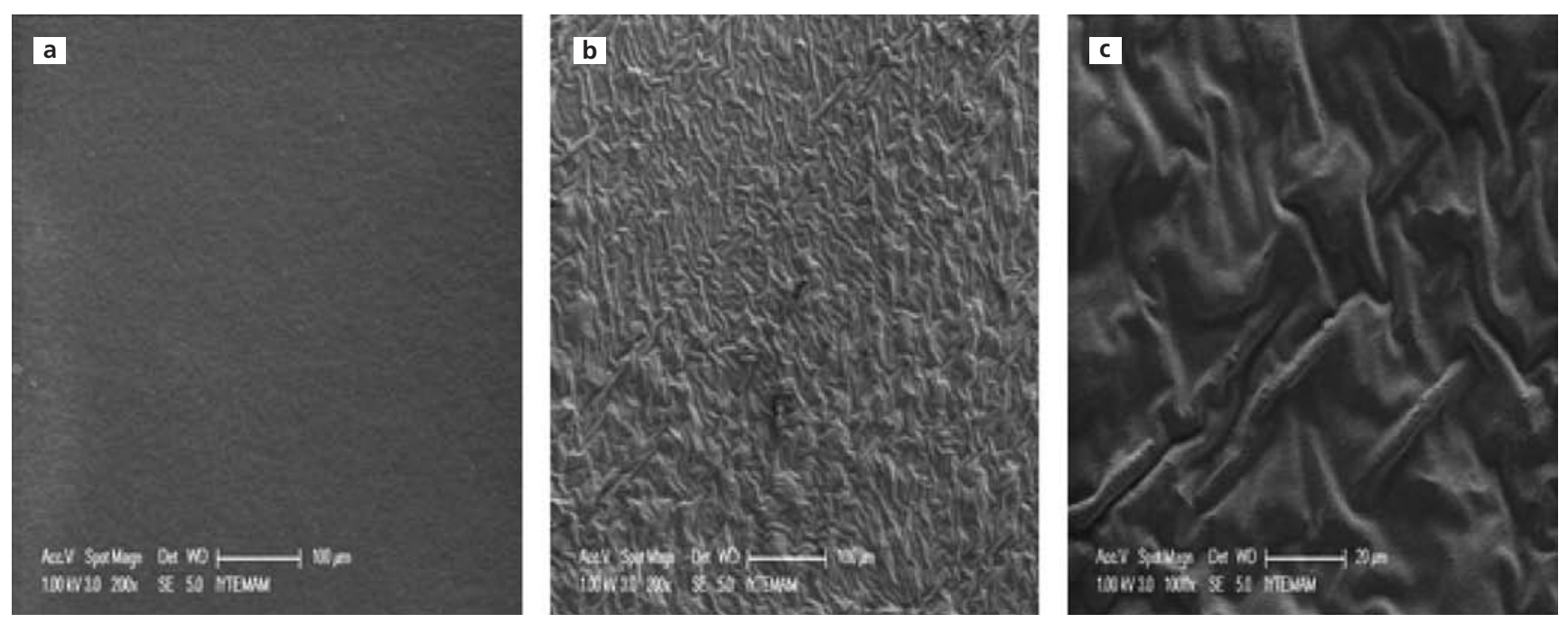

Figure 1. Surface morphology of polymeric films unimplanted PLC surface (a) and ion bombarded surfaces (b, c). Growth of deposited Au layer, island growth and coalescence by ion bombardment are observed. 
a

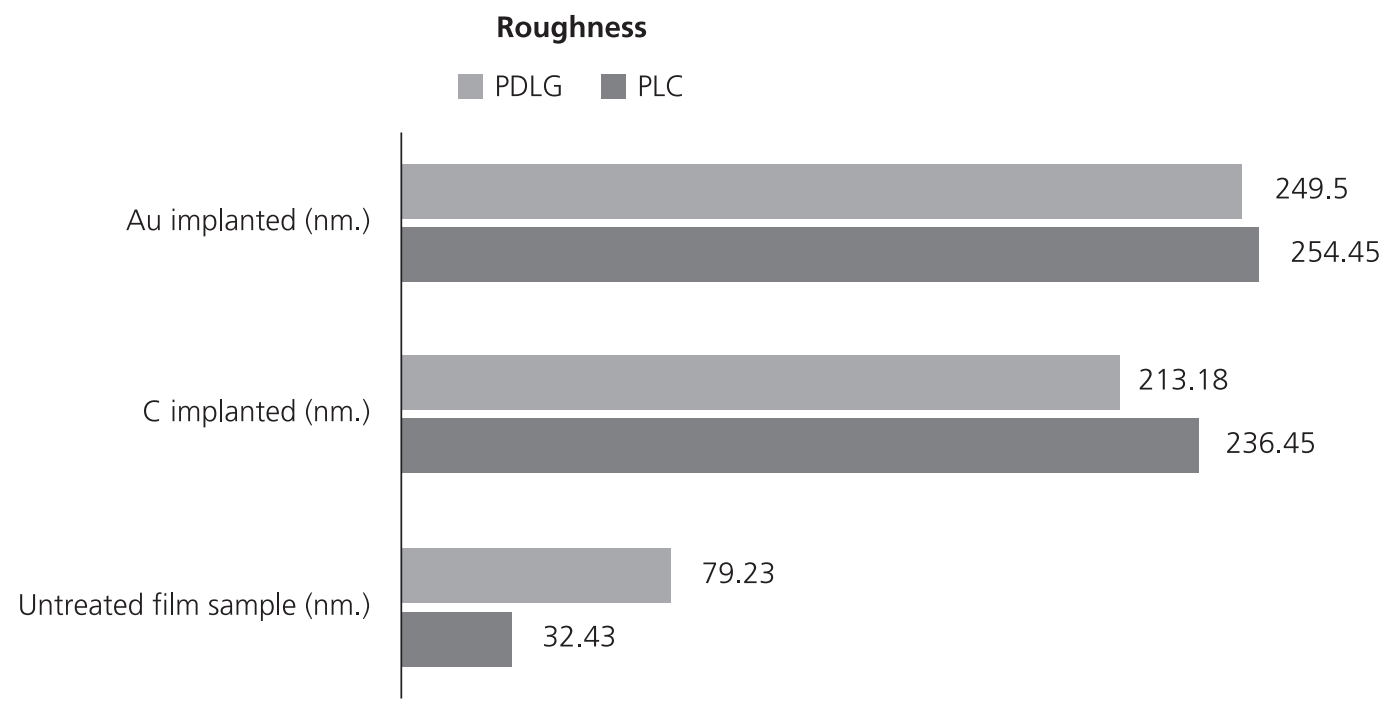

b
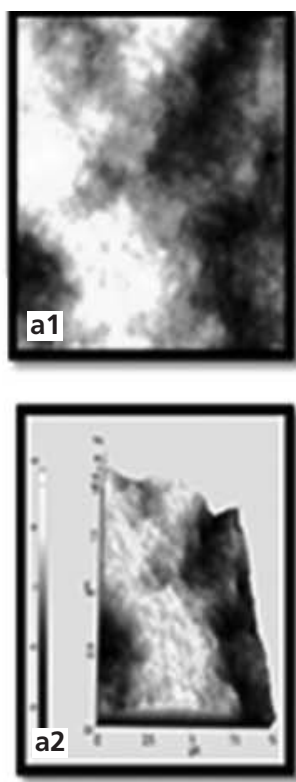

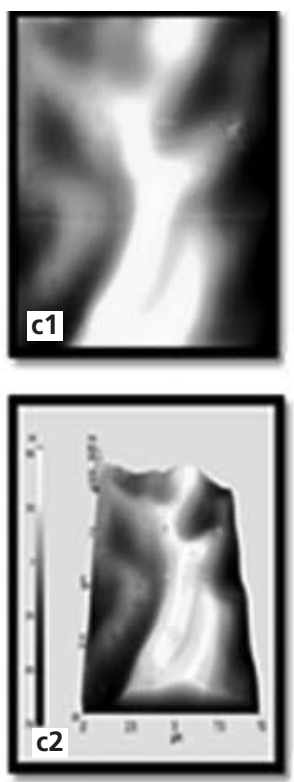
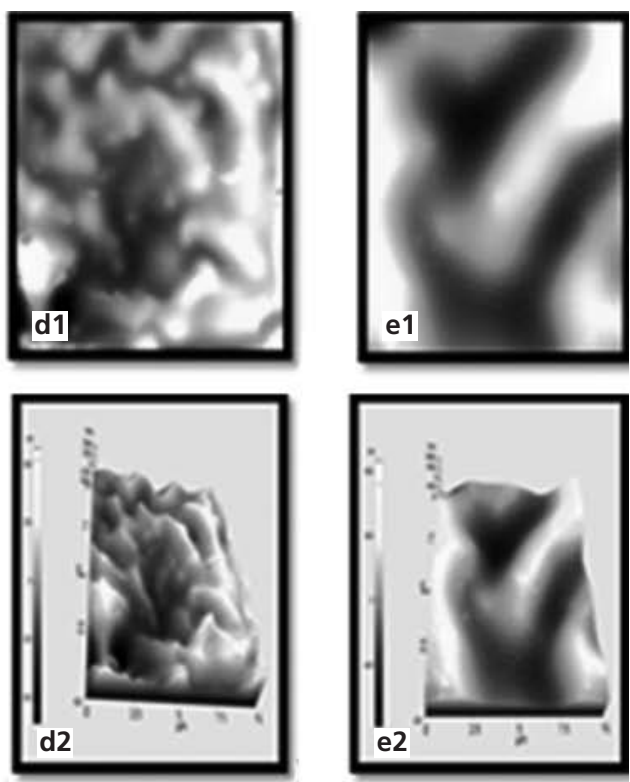

Figure 2. (a) Surface roughness (nm.) of untreated and Au and C ion implanted PDLG and PLC samples. Surface roughness values increased by ion bombardment. (b) Topographical changes by ion bombardement on PLC samples. Images taken by AFM in order to show nanoscaled textures on the surfaces. PLC film samples were ion implanted with the dose value of $(\mathrm{a} 1,2), 1 \times 10^{14}(\mathrm{~b} 1,2), 1 \times 10^{15}(\mathrm{c} 1,2), 1 \times 10^{16}(\mathrm{~d} 1,2), 5 \times 10^{16}(\mathrm{e} 1,2) 1 \times 10^{17}$ ion/ $\mathrm{cm}^{2}$.

To investigate the effects of pattern geometry and size on neural cell morphology and spreading, we focused on lamellar patterns on PLC sample. After sterilization, polymeric films were incubated with cells without any further surface modification. Cell contrast ratio is calculated for all PLC, PDLG and PLA for both Au and $\mathrm{C}$ bombarded samples (Figure 3). We took SEM images of PLC, PDLG and PLA (PDLG and PLA images are not shown) samples in order to observe mor- phological changes on the cells with respect to different ions and as well as the untreated samples. There were almost no morphological changes on the unimplanted surfaces compared to implanted samples where neuronlike cell morphology was observed. Neurites formed bridges between the surface wrinkles and aligned themselves with these bridges. Besides, neurite bridges lengthened to other cells and spread as neurons did (Figure 4). 




\begin{tabular}{|c|c|c|c|}
\cline { 2 - 4 } \multicolumn{1}{c|}{} & PLA & PDLG & PLC \\
\hline Au implanted sample & 3.5 & 1.45 & 2.85 \\
\hline C implanted sample & 2 & 4 & 3.8 \\
\hline
\end{tabular}

Figure 3. Cell contrast ratio of B35 cells on Au and C ion implanted different polymeric surfaces (PLA, PDLG and PLC).

\section{Discussion}

In this study, we used different polymers and modified the polymer surfaces with different ions to change surface topology to examine it effects on neural cell morphology. Au and $\mathrm{C}$ bombardment significantly increased surface roughness and this stimulated a higher cell attachment to the material surface. On the other hand, we observed that PLC is the best polymer for cell growth and proliferation. We clearly observed the extracellular matrix formation, cell spread and neurite formation on implanted samples.

Although we obtained reproducible pattern structures and sizes, the structural properties of the polymeric films differ significantly for each condition..$^{[7]}$ Importantly, this technique is applicable to a variety of photo-cross-linkable materials. For instance, for methacrylated hyaluronic acid gels. ${ }^{[8,9]}$

Increased surface roughness of materials will provide an increase on the cell attachment. Regardless of cell type, all adherent cells first, need to attach surface to proliferate and show their morphology. It has been shown that cell spreading elongated facilitates calcium deposition, ${ }^{[10,11]}$ whereas rounded cells shape in circular with low spreading allows for maximum lipid storage..$^{[12,13]}$ Here, we observed that control of surface structure morphologically using by ion beam bombardement technics could directly effect neural cell attachment and neurite extension.
Recent studies on ion implantation also questioned the use of this technique in nerve regeneration. ${ }^{[7,14,15]}$ Ishikawa et al. ${ }^{[14]}$ studied negative ion implantation on polymer surfaces and showed that PC12 cells were able to extend neurites. Improved and selective attachment properties of nerve cells, cultured in vitro, as well as their neurites were obtained.

In this study, the best cell attachment and neurite formation were observed on PLC samples. Ion bombardment increased the cell attachment. Cells attached and spread better on ion implanted surfaces. On $\mathrm{C}$ bombarded surfaces, we were able to observe a better neurite formation. When we compare the length of neuritis, best results were found in the $\mathrm{C}$ implanted samples. On the other hand, a better cell spread was observed on Au bombarded samples. We observed an extracellular matrix-like structure, which is a significant signal for cell viability, on implanted samples. This structure is more prominent on $t$ Au implanted samples where cell spread is also more apparent. When there is no extracellular matrix-like structure on unimplanted samples, this can be evaluated as a signal for a fitting environment created with ion implantation for cell growth and proliferation.

\section{Conclusion}

Our results strongly indicate the influence of surface modification by ion treatment on cell attachment, cell growth, cell proliferation and cellular morphology com- 

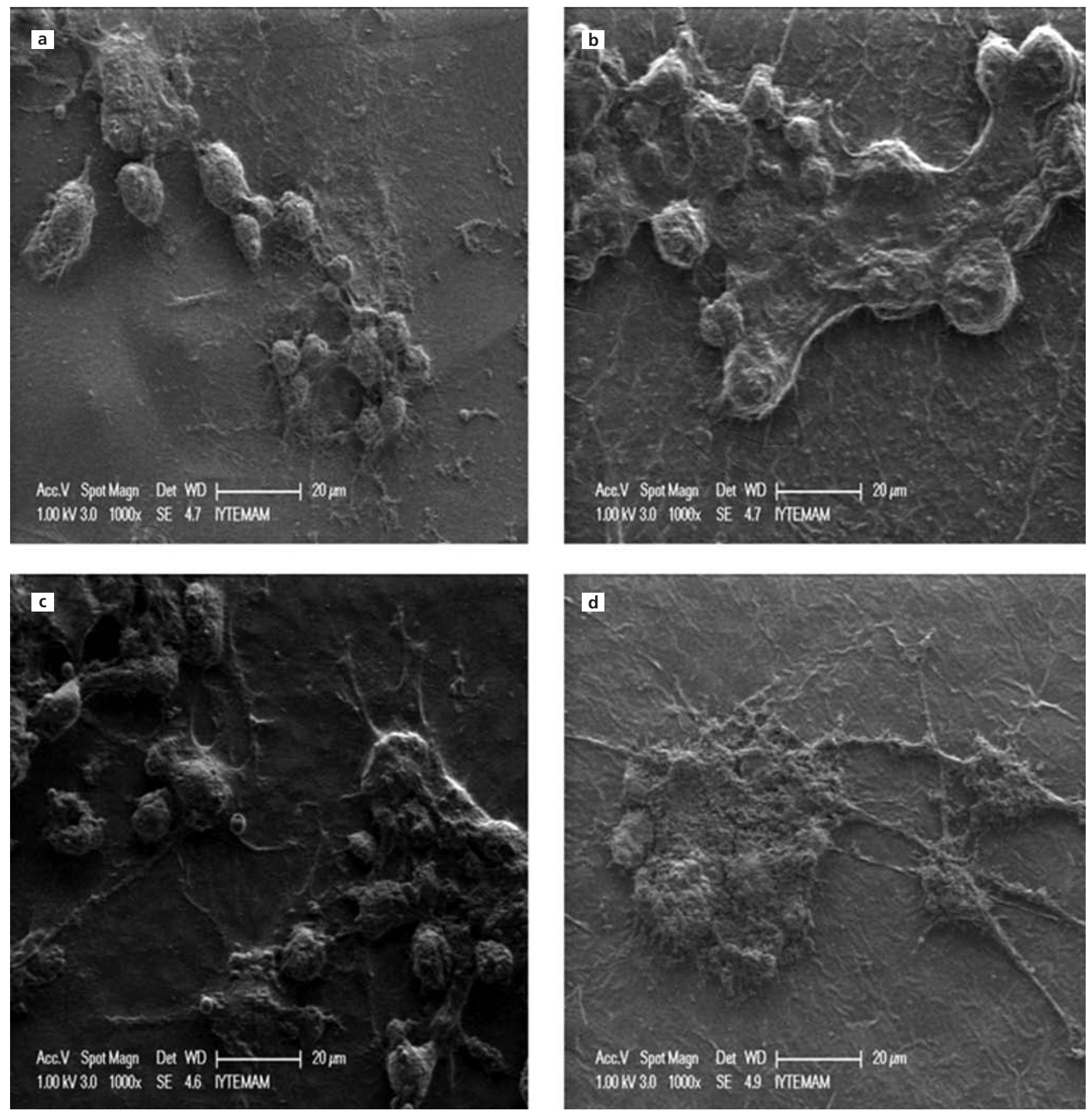

Figure 4. Cell morphology on differently textured ion beam bombarded surfaces. Polymeric film samples are compared as untreated (a), treated by $\mathrm{Au}$ (b), and C-ion bombarded (c and d) (SEM-1000X).

pared to unimplanted samples. These results are important to show that we can create a viable environment for cells where they secrete their own extracellular matrix and show their own phenotype and morphology without getting stressed. We have a great control over the surface topology just by changing the ion dose value and energy which makes it possible to create desired surface structures for different applications.

\section{Acknowledgements}

The authors would like to acknowledge funding from TUBITAK 108M391. The authors are also grateful to 
Ege University Bioengineering Department Cell Culture Facilities, İsmet Deliloğlu Gürhan, Feyzan Ozdal Kurt for helpful discussions and protocols, and to Sultan Gülce İz for assistance with cell culture experiments.

\section{References}

1. Chu PK, Chen JY, Wang LP, Huang N. Plasma-surface modification of biomaterials. Mater Sci Eng R 2002;36:143-206.

2. Lerouge S, Fozza AC, Wertheimer MR, Marchand R, Yahia LH. Sterilization by low-pressure plasma: the role of vacuum-ultraviolet radiation. Plasmas Polym 2000;5:31-46.

3. Braceras I, Alava JI, Goikoetxea L, de Maeztu MA, Onate JI. Interaction of engineered surfaces with the living world: ion implantation vs. osseointegration. Surf Coat Tech 2007;201: 8091-8.

4. Brown IG, Bjornstad KA, Blakely EA, Galvin JE, Monteiro OR, Sangyuenyongpipat $\mathrm{S}$. Growth of large patterned arrays of neurons using plasma methods. Plasma Phys Control Fusion 2003;45:54754.

5. Sokullu-Urkac E, Oztarhan A, Tihminlioglu F, Kaya N, Ila D, Muntele C, Budak S, Oks E, Nikolaev A, Ezdesir A, Tek Z. Thermal characterization of $\mathrm{Ag}$ and $\mathrm{Ag}+\mathrm{N}$ ion implanted ultrahigh molecular weight polyethylene (UHMWPE). Nucl Instrum Methods Phys Res B, Beam Interact Mater At 2007:261;699-703.

6. Sokullu Urkac E, Oztarhan A, Tihminlioglu F, Nikolaev A, Brown I. Oxidation behavior of $\mathrm{C}$-and $\mathrm{Au}$ ion-implanted biodegradable polymers. IEEE Transactions on Plasma Science 2012;40:863-9.



7. Tsuji H, Sommani P, Kitamura T, Hattori M, Sato H, Gotoh Y, Ishikawa J. Nerve-cell attachment properties of polystyrene and silicone rubber modified by carbon negative-ion implantation. Surf Coat Tech 2007;201:8123-6.

8. Chung C, Burdick JA. Influence of three-dimensional hyaluronic acid microenvironments on mesenchymal stem cell chondrogenesis. Tissue Eng Part A 2009;15:243-54.

9. Khetan S, Katz JS, Burdick JA. Sequential crosslinking to control cellular spreading in 3-dimensional hydrogels. Soft Matter 2009;5:1601e6.

10. Parfitt AM. Age-related structural changes in trabecular and cortical bone: cellular mechanisms and biomechanical consequences. Calcif Tissue Int 1984;36:123-8.

11. Sikavitsas VI, Temenoff JS, Mikos AG. Biomaterials and bone mechanotransduction. Biomaterials 2001;22:2581-93.

12. Gregoire FM, Smas CM, Sul HS. Understanding adipocyte differentiation. Physiol Rev 1998;78:783-809.

13. Grigoriadis AE, Heersche JN, Aubin JE. Differentiation of muscle, fat, cartilage, and bone from progenitor cells present in a bonederived clonal cell population: effect of dexamethasone. J Cell Biol 1988;106:2139-51.

14. Ishikawa J, Tsuji H, Sato H, Gotoh Y. Ion implantation of negative ions for cell growth manipulation and nervous system repair. Surf Coat Tech 2007;201:8083-90.

15. Kobayashi T, Katou R, Yokota T, Suzuki Y, Iwaki M, Terai T. Surface modification of silicone sheets and tubes using plasmabased ion implantation. Surf Coat Tech 2007;201:8039-42.
Correspondence to: Emel Sokullu, PhD

Department of Bioengineering, Faculty of Architecture and Engineering, Izmir Katip Çelebi University, Balatçık 35620, Çiğli, Izmir, Turkey Phone: +905332300582 e-mail: emelsu@gmail.com

Conflict of interest statement: No conflicts declared.

This is an open access article distributed under the terms of the Creative Commons Attribution-NonCommercial-NoDerivs 3.0 Unported (CC BY-NCND3.0) Licence (http://creativecommons.org/licenses/by-nc-nd/3.0/) which permits unrestricted noncommercial use, distribution, and reproduction in any medium, provided the original work is properly cited. Please cite this article as: Sokullu E, Ersoy F, Öztarhan A, Brown IG. Controlling cell morphology on ion beam textured polymeric surfaces. Anatomy 2015;9(3):135-141. 